\section{BRAZIULIAN JOURNAL}

OF MEDICAL AND BIOLOGICAL RLSH.ARCH

www.bjournal.com.br
ISSN 0100-879X

Volume 43 (01) 1-123 January 2010

BIOMEDICAL SCIENCES

AND

CLINICAL INVESTIGATION

Braz J Med Biol Res, J anuary 2010, Volume 43(1) 120-123

Diphtheria toxin IgG levels in military and civilian blood donors in Rio de Janeiro, Brazil

F.A.B. Speranza, S.K. Ishii, R. Hirata Jr., A.L. Mattos-Guaraldi and L.G. Milagres

The Brazilian Journal of Medical and Biological Research is partially financed by
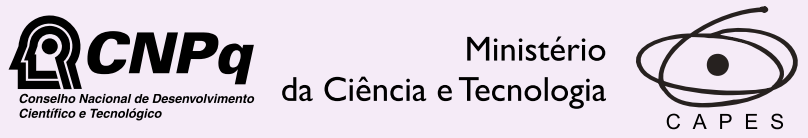

Ministério da Educação

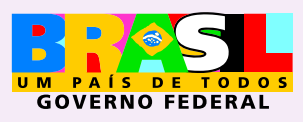

Institutional Sponsors 


\title{
Diphtheria toxin IgG levels in military and civilian blood donors in Rio de Janeiro, Brazil
}

\author{
F.A.B. Speranza ${ }^{1}, 2$, S.K. Ishii ${ }^{1}$, R. Hirata Jr. ${ }^{2}$, A.L. Mattos-Guaraldi ${ }^{2}$ \\ and L.G. Milagres ${ }^{2}$ \\ ${ }^{1}$ Instituto de Biologia do Exército, and ${ }^{2}$ Faculdade de Ciências Médicas, \\ Universidade do Estado do Rio de Janeiro, Rio de Janeiro, RJ, Brasil
}

\begin{abstract}
Serologic data on diseases that are preventable by vaccines are necessary to evaluate the success of immunization programs and to identify susceptible subgroups. In the present study, we determined serum IgG levels against diphtheria toxin of military and civilian blood donors ( $\mathrm{N}=75 ; 69.3 \%$ males and $30.7 \%$ females) aged $18-64$ years, from the Brazilian Army Biology Institute, Rio de Janeiro, using a commercial diphtheria kit (Diphtheria IgG ELISA; IBL, Germany). Most (63\%) unprotected military donors were from the older age group of 41 to 64 years. In contrast, the majority (71\%) of young military donors (18 to 30 years) were fully protected. About half of the military donors aged 31 to 40 years were protected against diphtheria. Among the civilians, about $50 \%$ of persons aged 18 to 30 years and 31 to 40 years had protective antibody levels against diphtheria as also did $64 \%$ of individuals aged 41 to 64 years. All civilians had a similar antibody response (geometric mean $=0.55 \mathrm{IU} / \mathrm{mL}$ ) independent of age group. Military donors aged $18-30$ years had higher IgG levels (geometric mean $=0.82 \mathrm{IU} / \mathrm{mL}$ ) than military donors of $41-64$ years (geometric mean $=0.51 \mathrm{IU} / \mathrm{mL} ; \mathrm{P}>0.05$ ). In conclusion, the existence of a considerable proportion of susceptible adults supports the position that reliable data on the immune status of the population should be maintained routinely and emphasizes the importance of adequate immunization during adulthood.
\end{abstract}

Key words: Diphtheria protective antibodies; Military personnel; Blood donors; Age influence

\section{Introduction}

Diphtheria is a life-threatening disease that can be prevented by immunization $(1,2)$. The recommended vaccination schedule in Brazil consists of three doses of diphtheria-tetanus-pertussis (DTP) vaccine in the first year of life, followed by a booster dose at 5-6 years of age. In 2002, the Public Health Agency of Rio de Janeiro (3) reported a shift in the age distribution of cases of diphtheria to persons older than 15 years. Current information also indicates the circulation of Corynebacterium diphtheriae in our population, including cancer patients and healthy vaccinated adults $(4,5)$.

In response to the huge epidemic that hit the countries of the Russian confederation in the early 1990's (8), the Brazilian Ministry of Health recommended, since 2004, an additional diphtheria-tetanus booster dose to be provided every 10 years (6). However, there are few published data regarding regular immunization coverage and the immunity of the Brazilian adult population (7).

A survey carried out on serum samples collected from blood donors at a University Hospital of Rio de Janeiro from July to October 2002 (8) showed that a high proportion $(\sim 70 \%)$ of individuals from 18 to 30 years of age had nonprotective antibody levels against the diphtheria toxin. In view of the potential risk of low antibody levels in the adult population, these data highlight the need for additional seroepidemiological surveys in Brazil.

Due to the possibility of outbreaks of respiratory diphtheria among the military, several studies have been performed in order to assess the immune status of soldiers against diphtheria in different countries (9-12). To our knowledge, there are no published data regarding antibody levels against diphtheria toxin in Brazilian individuals in the military

Correspondence: L.G. Milagres, Disciplina de Microbiologia, Imunologia e Parasitologia, Faculdade de Ciências Médicas, UERJ, Av. 28 de Setembro, 87, Fundos, $3^{\circ}$ andar, 20551-030 Rio de Janeiro, RJ, Brasil. Fax: +55-21-2587-6476.

E-mail: milagreslucimar@gmail.com

Received June 5, 2009. Accepted December 3, 2009. Available online December 18, 2009. Published January 11, 2010. 
service. In the present study, we have determined serum IgG levels against diphtheria toxin using a commercial diphtheria-ELISA kit of military and civilian blood donors from the Army Biology Institute of Rio de Janeiro.

\section{Subjects and Methods}

\section{Study subjects}

This study enrolled 75 blood donors who represented about one third of all blood donors in the year of 2008 from Instituto de Biologia do Exército (IBEx), Rio de Janeiro. Participants ranged in age from 18 to 64 years, 23 were females and 52 were males. Military personnel consisted of 36 individuals ( 9 females and 27 males). Civilians accounted for 39 individuals (14 females and 25 males) who were relatives or friends of military personnel. Blood samples were collected between July 2006 and May 2008. Selection criteria were based on procedures including a prospective written survey designed to disqualify individuals associated with a range of known risk categories and a retrospective investigation of serological testing aiming to eliminate individuals exhibiting evidence of prior exposure to a range of known pathogens.

The procedures used in this study were approved by the Ethics Committee of Hospital Universitário Pedro Ernesto, Universidade do Estado do Rio de Janeiro (HUPE/UERJ), protocol number 1548- CEP/HUPE of October 30, 2006 and written informed consent was obtained from all volunteers during an interview.

\section{Diphtheria antibody measurement}

Diphtheria toxin IgG-specific antibody titers were determined using a commercial ELISA kit with titers $(\mathrm{IU} / \mathrm{mL})$ calibrated against the WHO standard NIBSC 91/534, purchased from Immuno-Biological Laboratories (Germany). The titers were classified into three groups: $<0.1 \mathrm{IU} / \mathrm{mL}$, between 0.1 and $0.9 \mathrm{IU} / \mathrm{mL}$ and $\geq 1.0 \mathrm{IU} / \mathrm{mL}$, respectively indicating unprotected, partially protected, and fully protected individuals (8). ELISA showed $96 \%$ (98/102) specificity, $55.3 \%$ (21/38) sensitivity, $84 \%$

Table 1. Percentage of blood donors with antibodies to diphtheria toxin stratified by age.

\begin{tabular}{|c|c|c|c|c|}
\hline \multirow{3}{*}{ Age group (years) } & \multicolumn{4}{|c|}{$\lg G(I U / m L)$ anti-diphtheria toxin } \\
\hline & \multicolumn{2}{|c|}{$\geq 0.1$ to $<1$} & \multicolumn{2}{|c|}{$\geq 1$} \\
\hline & Civilian ${ }^{a}$ & Military & Civilian ${ }^{a}$ & Military \\
\hline $18-30$ & $46(6 / 13)$ & $29(6 / 21)$ & $54(7 / 13)$ & $71(15 / 21)$ \\
\hline $31-40$ & $57(8 / 14)$ & $43(3 / 7)$ & $43(6 / 14)$ & $57(4 / 7)$ \\
\hline $41-64$ & $36(4 / 11)$ & $63(5 / 8)$ & $64(7 / 11)$ & $38(3 / 8)$ \\
\hline Total: 18 to 64 & $46(18 / 39)$ & $39(14 / 36)$ & $51(20 / 39)$ & $61(22 / 36)$ \\
\hline
\end{tabular}

aOne individual of 49 years of age (4\%) showed specific $\lg G<0.1 \mathrm{IU} / \mathrm{mL}$.
$(21 / 25,95 \% \mathrm{Cl}=78-90)$ and $85 \%(98 / 115,95 \% \mathrm{Cl}=79-91)$ positive and negative predictive values, respectively, with correlation between neutralization test (antibody levels $\geq 0.1 \mathrm{IU} / \mathrm{mL}$ ) and ELISA (titers $\geq 1 \mathrm{IU} / \mathrm{mL}$ ) corresponding to $k=0.575 \pm 0.081(P<0.001)(8)$.

\section{Statistical analysis}

The levels of significance of the differences between serum antibody levels and groups were examined by the paired or unpaired $t$-test (parametric tests). The Mann-Whitney test was used for data that did not have a normal distribution. All analyses were performed with the GraphPad-Prism software, version 4.02. P $<0.05$ was taken to be significant.

\section{Results}

The geometric mean of $\lg G$ anti-diphtheria toxin levels of the military and civilian population classified by age was similar $(P>0.05)$ for all age groups, ranging from 0.51 to $0.82 \mathrm{IU} / \mathrm{mL}$. Although large, the difference in antibody levels between military donors aged 18-30 years (geometric mean $=0.82 \mathrm{IU} / \mathrm{mL}$ ) and $41-64$ years (geometric mean $=0.51 \mathrm{lU} / \mathrm{mL}$ ) was not statistically significant $(P=0.053)$. There were no important differences in diphtheria antibody levels between males and females of the civilian or military groups.

The data in Table 1 show important differences ( $P$ $>0.05$ ) in the percentage of individuals with diphtheria protective antibody levels in both the civilian and military groups. Most (63\%) unprotected or partially protected military donors were from the older age group of 41 to 64 years. In contrast, the majority $(71 \%)$ of young military donors (18 to 30 years) were fully protected against the disease. About half (43\%) of the military donors aged 31 to 40 years were protected against diphtheria. Among the civilians, about $50 \%$ of the individuals from all age groups had diphtheria protective antibodies.

Figure 1 shows a significant negative correlation between age and IgG levels for approximately $40 \%$ of the military donors. No important correlation between antibody levels and age was detected for civilians.

According to our records of vaccination during adulthood, 24 military donors and 15 civilians reported that they received a booster dose from zero to 12 years after the primary immunization (mean of 4.2 years). Nonetheless, about half of the individuals remained only partially protected after the booster injection of diphtheria toxoid (DT) vaccine (data not shown). These data indicate that specific studies should be conducted to define the ideal revaccination schedule for the adult population, including the use of a booster dose with higher-antigen DT. 


\section{Discussion}

Despite the dramatic decline in the incidence of diphtheria after routine childhood immunization (2), studies from Europe (13) and North America (14) have shown that the adult population is not fully protected against the disease. During an epidemic in Eastern Europe the highest mortality rate (62\%) was detected among persons aged 41 to 64 years (15). Nowadays, booster doses of diphtheria toxoid in Brazil and many other countries are recommended every 10 years for adults, but this recommendation is not regularly enforced $(6,15)$.

Protection against diphtheria is associated with the development of toxin neutralizing antibodies (16). Due to the inherent technical difficulties in the determination of neutralizing antibody titers, in many cases commercially available ELISA kits are used to investigate IgG antibody levels to DT. The ELISA kit used in the present study was previously evaluated in our laboratory in relation to the toxin neutralization test in Vero cells (8). The results indicated that IgG concentration determined by the kit used in this study is not accurate in detecting antibody titers below 0.1 $\mathrm{IU} / \mathrm{mL}$, as demonstrated earlier (17), suggesting that the percent of individuals not protected could be even higher than that reported here.

Our data indicate a significant difference in terms of serological protection against diphtheria between civilian and military blood donors. A greater percentage $(71 \%)$ of young military donors (18 to 30 years) was protected compared to civilians $(54 \%)$ of the same age group. The reasons for these differences could be due to a higher rate of compliance with booster vaccination in the young military group compared to civilians.

A previous survey (18) evaluating the serum toxin neutralizing antibodies in Brazilian blood donors showed that the highest percentage $(41.6 \%)$ of subjects susceptible to diphtheria was in the age range of 41 to 50 years. In the present study, we observed that about $63 \%$ of military donors in the 41 - to 64 -year-old age group were not protected, compared to $36 \%$ of unprotected civilians. Therefore, the military donors aged 41 to 64 years investigated in the present study should receive a complete vaccination series or a booster dose of diphtheria vaccine as soon as possible.

Concerns also remain regarding the civilians, since only about $50 \%$ of these individuals from all age groups studied were protected. A study investigating human immunity to DT in São Paulo (2001 to 2003) showed that $82 \%$ of individuals aged 40 to 59 years were susceptible to the disease (19). Overall, these data suggest that five years after the Brazilian Ministry of Health recommended additional booster doses to be provided every 10 years,
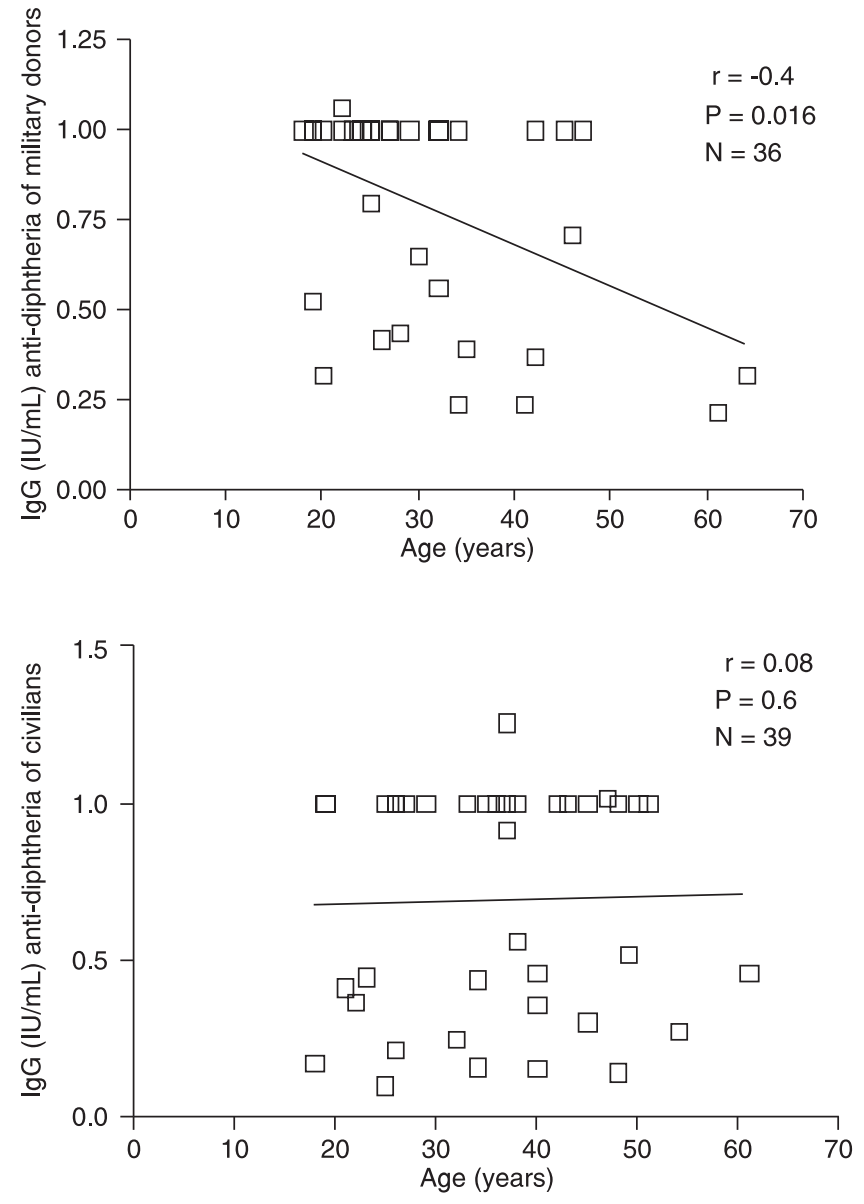

Figure 1. Correlation between antibodies to diphtheria and age. A significant $(P=0.016)$ negative correlation coefficient $(r=-0.4)$ was demonstrated for antibodies versus age in the military group. For civilians, there was no association $(r=0.08 ; P=0.6)$ between antibody concentration and age.

the adult population in our country is not fully protected against diphtheria.

Diphtheria has been decreasing in Brazil since the 1990 's, but the exact incidences of the disease are poorly recorded in most of the Brazilian states (20). Several factors may influence the maintenance of diphtheria protective antibody levels including the socio-economic status, the exposure of individuals to C. diphtheriae, and the adherence to revaccination campaigns. In fact, McQuillan et al. (14) reported that at each increasing level of education, a higher percentage of individuals had protective antibodies to diphtheria and tetanus toxins. In contrast, persons living at or above the poverty level were less likely to be protected from diphtheria. The toxoid concentration may also influence the immunogenicity of the vaccine. In a recent outbreak of diphtheria among military trainees, the risk of disease was lower and 
diphtheria antitoxin levels were higher among trainees who received their last booster dose with higher-antigen DT instead of lower-antigen dT (12).

In spite of the fact of the small sample size, the results of this study indicate that reliable data on the immune status of the population should be maintained routinely. Data described here emphasize that more effort is required to encourage diphtheria vaccination boosters for military and civilian adults, especially for the 41- to 64-

\section{References}

1. Bonnet JM, Begg NT. Control of diphtheria: guidance for consultants in communicable disease control. World Health Organization. Commun Dis Public Health 1999; 2: 242249.

2. Galazka A. The changing epidemiology of diphtheria in the vaccine era. J Infect Dis 2000; 181 (Suppl 1): S2-S9.

3. Secretaria de Saúde do Estado do Rio de Janeiro - SESRJ. Proporção de casos e óbitos por difteria segundo faixa etária, 1978-2002. Rio de Janeiro: SES-RJ/SUSC/CE/Assessoria de Doenças Imunoprevisíveis; 2002.

4. Mattos-Guaraldi AL, Formiga LC, Camello TC, Pereira GA, Hirata R Jr, Halpern M. Corynebacterium diphtheriae threats in cancer patients. Rev Argent Microbiol 2001; 33: 96-100.

5. Mattos-Guaraldi AL, Formiga LCD, Marques EA, Pereira GA, Moreira LO, Pimenta FP, et al. Diphtheria in vaccinated adult in Rio de Janeiro. Braz J Microbiol 2001; 32: 236-239.

6. Ministério da Saúde. Brasil. Portaria No. 597/GM, de 08 de abril de 2004. Institui em todo território nacional, os calendários de vacinação. Brasília: Diário Oficial da União (República Federativa do Brasil), 12 de abril. Seção 1. 69: $47 ; 2004$.

7. Fundação Nacional de Saúde. Difteria: situação atual da doença. Funasa http://www.funasa.gov.br/guia-epi/htm/ doenças/difteria/index.htm; 2002.

8. Damasco PV, Pimenta FP, Filardy AA, Brito SM, Andrade AF, Lopes GS, et al. Prevalence of IgG diphtheria antitoxin in blood donors in Rio de Janeiro. Epidemiol Infect 2005; 133: 911-914.

9. Masterton RG, Tettmar RE, Pile RL, Jones J, Croft KF. Immunity to diphtheria in young British adults. J Infect 1987; 15: 27-32.

10. Cohen D, Katzenelson E, Green M, Slepon R, Bercovier $\mathrm{H}$, Danon Y. Prevalence and correlates of diphtheria toxin antibodies among young adults in Israel. $J$ Infect 1991; 23: 117-121.

11. Liashenko I, Velichko MA. [The diagnostic and treatment characteristics of diphtheria in troop units and military medi- year age stratum in our community.

\section{Acknowledgments}

Research supported by CNPq, CAPES, FAPERJ, SR-2/ UERJ, Programa de Núcleo de Excelência (PRONEX) of the Brazilian Ministry of Science, Rio de Janeiro Technology, the Brazilian Ministry of Health STD/AIDS Program, and the Brazilian Army Biology Institute (IBEx). cal institutions]. Voen Med Zh 1993; 80: 37-40.

12. Ohuabunwo C, Perevoscikovs J, Griskevica A, Gargiullo P, Brilla A, Viksna L, et al. Respiratory diphtheria among highly vaccinated military trainees in Latvia: improved protection from DT compared with Td booster vaccination. Scand $J$ Infect Dis 2005; 37: 813-820.

13. Volzke H, Kloker KM, Kramer A, Guertler L, Doren M, Baumeister SE, et al. Susceptibility to diphtheria in adults: prevalence and relationship to gender and social variables. Clin Microbiol Infect 2006; 12: 961-967.

14. McQuillan GM, Kruszon-Moran D, Deforest A, Chu SY, Wharton M. Serologic immunity to diphtheria and tetanus in the United States. Ann Intern Med 2002; 136: 660-666.

15. Brennan M, Vitek C, Strebel P, Wattigney W, Bisgard K, Brisgalov $S$, et al. How many doses of diphtheria toxoid are required for protection in adults? Results of a case-control study among 40- to 49-year-old adults in the Russian Federation. J Infect Dis 2000; 181 (Suppl 1): S193-S196.

16. Ipsen J. Circulating antitoxin at the onset of diphtheria in 425 patients. J Immunol 1946; 54: 325.

17. Melville-Smith M, Balfour A. Estimation of Corinebacterium diphtheriae anti toxin in human sera: a comparison of an enzyme-linked immunosorbent assay with the toxin neutralization test. J Med Microbiol 1988; 25: 279-283.

18. Pimenta FP, Damasco PV, Cerbino NJ, Lopes GS, Hirata $\mathrm{R}$ Jr, Milagres LG, et al. Diphtheria-neutralizing antibody levels in healthy adults from Rio de Janeiro, Brazil. Mem Inst Oswaldo Cruz 2006; 101: 459-462.

19. Divino-Goes KG, Moraes-Pinto MI, Dinelli MI, Casagrande ST, Bonetti TC, Andrade PR, et al. Prevalence of diphtheria and tetanus antibodies and circulation of Corynebacterium diphtheriae in São Paulo, Brazil. Braz J Med Biol Res 2007; 40: 1681-1687.

20. Sistema de Informação de Agravos de Notificação - Sinan. http://dtr2009.saude.gov.br/sinanweb/index. php?name=Tnet. Accessed May 15, 2009. 